\title{
Growth and Instability in Area, Production and Yield of Chilli in India
}

\author{
P. A. Gade ${ }^{1}$, S. S. More ${ }^{2}$, R. D. Shelke ${ }^{1 *}$ and A. R. Nalegaonkar ${ }^{1}$ \\ ${ }^{1}$ Department of Agricultural Economics, College of Agricultural, Latur, India \\ ${ }^{2}$ Department of Agricultural Economics, College of Agricultural, Parbhani, India \\ *Corresponding author
}

\begin{tabular}{l} 
K e y w o r d s \\
$\begin{array}{l}\text { Chilli, Growth and } \\
\text { instability, Area, } \\
\text { Production and } \\
\text { yield }\end{array}$ \\
Article Info \\
$\begin{array}{l}\text { Accepted: } \\
20 \text { October } 2020 \\
\text { Available Online: } \\
10 \text { November } 2020\end{array}$ \\
\hline
\end{tabular}

\section{A B S T R A C T}

Chilli (Capsicum annuum L.) is an important vegetable cum spice crop valued for its aroma, taste, flavor and pungency grown in all parts of world. It belongs to the family solanaceae with the chromosome number $2 n=24$ and centre of origin of hot chilli is Mexico. chilli is one of the most valuable spice crop than other spices. Chilli is cultivated largely for its fruit all over the India. It is used in India as a principle ingredient of various curries, and chutneys, it is also used for vegetables, spices, medicinal, condiments, sauces and pickles with great nutritional value. Majority of chilli grown in India is cultivated in states of Andhra Pradesh, Maharashtra, Karnataka, Gujarat, Tamil Nadu and Orissa. Andhra Pradesh stands first in the list of foremost chilli producing states in India and also constitutes the highest areas for chilli cultivation in the country, occupies 49 per cent share in the Indian total production of chilli. The present study based on the secondary data, were collected from Horticultural statistics at glance-2018 and websites such like www.apeda.com, www.indiaspices.com and www.indiaagristat.com. Area, production and productivity data of chilli were obtained for 23 years from the year 1995-96 to 201718. To estimate the growth rate and instability in area, production and yield compound growth rate and Cuddy-Della Valle Instability Index was used. Analysis shows compound growth rate of area of chilli in India was negative and significant, whereas production and yield was positive and significant. Also observed that, area consist lower instability rate, were production as well as yield shows higher instability rate.

\section{Introduction}

Chilli (Capsicum annuum L.) is an important vegetable cum spice crop valued for its aroma, taste, flavor and pungency grown in all parts of world. It belongs to the family solanaceae with the chromosome number $2 n=24$ and centre of origin of hot chilli is Mexico. Chilli is cultivated from $3500 \mathrm{BC}$ and it is brought to Asia by Portuguese navigators during the $16^{\text {th }}$ century. Chilli is one of the most valuable spice crops than other spices. Chilli is cultivated largely for its fruit all over the India. It is used in India as a principle ingredient of various curries, and chutneys, it is also used for vegetables, spices, medicinal, condiments, sauces and pickles. Chilli has great nutritional value and medicinal properties, where extract from chilli i.e. capsicum has a tonic and 
carminative action. Taken devilishly it may cause gastro-enteritis. The enzyme isolated from chilli is used in the treatment of different types of cancers. Oleoresin capsicum is used in pain balms and vaporubs. Chilli has traditional remedy for, asthma, arthritis, blood clots, cluster, pains, headache and burns.

The Global area under chilli cultivation is 1.776 million hectare with a production of 7.182 million tones. The India's area under chilli cultivation is 316.47 thousand hectare and total chilli production is 3633.99 thousand MT. India, the world's biggest producer and the consumer of red spice, exported 44.90 Thousand MT. chilli, which worth of 22,074.05 lakhs during the year 2017-18 (Source - Horticulture statistics 2018). India has become world's largest producer and exporter of chilli, exporting to USA, UK, Saudi Arabia, Bangladesh, Pakistan, Sri Lanka, UAE, Singapore, Malaysia, Indonesia, Canada, Vietnam, Germany and many countries across the world. India and china are the largest exporter of chilli in the world with 25 per cent and 24 per cent share of total global exports, respectively. The demands for Indian chilli in the market of Malaysia, Bangladesh, Sri Lanka, UK and USA have been growing on an average between 20 to 25 per cent because of its quality and price competitiveness.

Majority of chilli grown in India is cultivated in states of Andhra Pradesh, Maharashtra, Karnataka, Gujarat, Tamil Nadu and Orissa. Andhra Pradesh stands first in the list of foremost chilli producing states in India and also constitutes the highest areas for chilli cultivation in the country. It occupies 49 per cent share in the Indian total production of chilli. Karnataka follows Andhra Pradesh, which shares 14 per cent followed by Orissa 7 per cent, Maharashtra 6 per cent and Madhya Pradesh 4 per cent of chilli production in the country. The major chilli producing states in
India namely Andhra Pradesh, Karnataka, Maharashtra, Orissa, Rajasthan and Tamil Nadu. They contribute around 86 per cent of total area under the cultivation of chilli in the country and 90 per cent of the total Indian Produce. Andhra Pradesh contributes to approximately 25 per cent of the total production. Presently India is the main source of Red chilli for International market. It consumes around 6.2 million tonnes of chilli i.e about 90 per cent of the total produce of the country. The demands from the chilli powder-producing sectors constitutes to 30 per cent of the total production in the country. Chilli powder, dried chilli, green chilli, pickled chilli and chilli oleoresins are some of the forms in which this crop is exported. It is estimated that around 25-30 per cent of chilli crop is used for powder preparation

The main objectives of this study includes to study growth and instability in area, production and productivity of chilli in India

\section{Materials and Methods}

The secondary data has been collected from, National horticulture board, Horticultural statistics at glance-2018 and websites viz., www.apeda.com, www.indiaspices.com and www.indiaagristat.com. The 23 years data regarding India's area, production and productivity collected from 1995-96 to 201718. Compound growth rate and Cuddy-Della Valle Instability Index was used to estimate growth and instability in area, production and yield.

\section{Growth rate}

The compound growth rate was computed based on its fit using non-linear models, especially, the exponential model conventionally, the compound growth rates were estimated after converting the growth model to semi-log form and estimated 
through Ordinary Least Square (OLS) technique assuming multiplicative error term. However, there are several problems associated with this technique including the difficulty in estimating standard error of estimates of original parameters. Hence, a non-linear estimation technique for solving exponential model assuming additive error terms was used to estimate the compound growth rates.

$\mathrm{Yt}=\mathrm{constant}^{*}(1+\mathrm{CGR})+\epsilon_{\mathrm{t}}$

Where,

$\mathrm{Yt}$ is the time series data for area/production/yield for years $t$

$\mathrm{T}$ is the time trends for years of interest,

$€ t$ is the error term and

CGR is compound growth rate for the period under consideration.

The Marquardt algorithm was used to estimate the parameters of equation. The data were smoothened by taking three year moving average to remove bias if any, induced by the outliers. The significance of regression coefficients was tested by applying standard ' $t$ ' test procedure.

\section{Instability Index: Cuddy-Della Valle Index}

Cuddy-Della Valle Instability Index was used to estimate the instability in area, production, and yield. This index is a modification of coefficient of variation (CV) to accommodate for trend, which is commonly present in time series economic data. It is superior over other scale dependent measures such as Standard Deviation or Root Mean Square of the residuals (RMSE) obtained from the fitted trend lines of the raw data and hence suitable for cross comparisons. The cuddy Della Index (IX) is calculated as follows.

$$
\mathbf{I x}=\mathbf{C V} \sqrt{(1-R)^{2}}
$$

Where,

$\mathrm{CV}=$ Coefficient of Variation $\left(\delta / \mathrm{x}^{-}\right)$

$R^{2}=$ Adjusted coefficient of multiple determination

Where, trend in the time series data in non significant, instability of that particular series was analyzed with the help of conventional statistical tool of instability i.e. coefficient of variation. The coefficient of variation $(\mathrm{CV})$ was calculated by using formula,

C V. (per cent $)=\frac{\text { Standard Deviation(a) }}{\text { Mean }} \times 100$

\section{Results and Discussion}

Growth in area, production and yield of chilli in India

Compound growth rates (CGR) of area, production and productivity of chilli was estimated and reported in table 1. Results revealed that, compound growth rate of area of chilli in India was negative and significant, whereas production and yield was positive and significant. The average area, production and yield of chilli during the study period were 814.59 thousand hectare, 1281.77 thousand MT and 1.59 MT, respectively. CGR of chilli area was -0.774 , for production and yield it was $3.647 \& 4.262$ per cent per annum, respectively. The growth of area, production and yield were statistically significant at 1 per cent level of significance. Standard Error of area, production and yield was, $0.237,0.416$ and 0.424 respectively. The observed " $\mathrm{t}$ " value for area was -3.27 , production 8.76 and yield 10.05. Compound growth of area shows negative, whereas CGR of production and yield shows positive nature. 
Table.1 Growth in area, production and yield of chilli in India (Area in "000" ha; production in '000'MT and yield in MT per ha.)

\begin{tabular}{|l|l|l|l|}
\hline Particulars & Area & Production & Yield \\
\hline Mean & 814.59 & 1281.77 & 1.59 \\
\hline CGR & $-0.774 * *$ & $3.647 * *$ & $4.262 * *$ \\
\hline SE & 0.237 & 0.416 & 0.424 \\
\hline “t” Value & -3.27 & 8.76 & 10.05 \\
\hline \multicolumn{4}{|c}{ (**indicates significance of value at 1 per cent) }
\end{tabular}

Table.2 Instability in area, production and yield of chilli in India

\begin{tabular}{|c|c|c|c|}
\hline Particulars & Area & Production & Yield \\
\hline CV & 0.09 & 0.26 & 0.30 \\
\hline CDI & 0.07 & 0.13 & 0.12 \\
\hline
\end{tabular}

Figure.1 Time sequence plot of area, production and yield of chilli in India

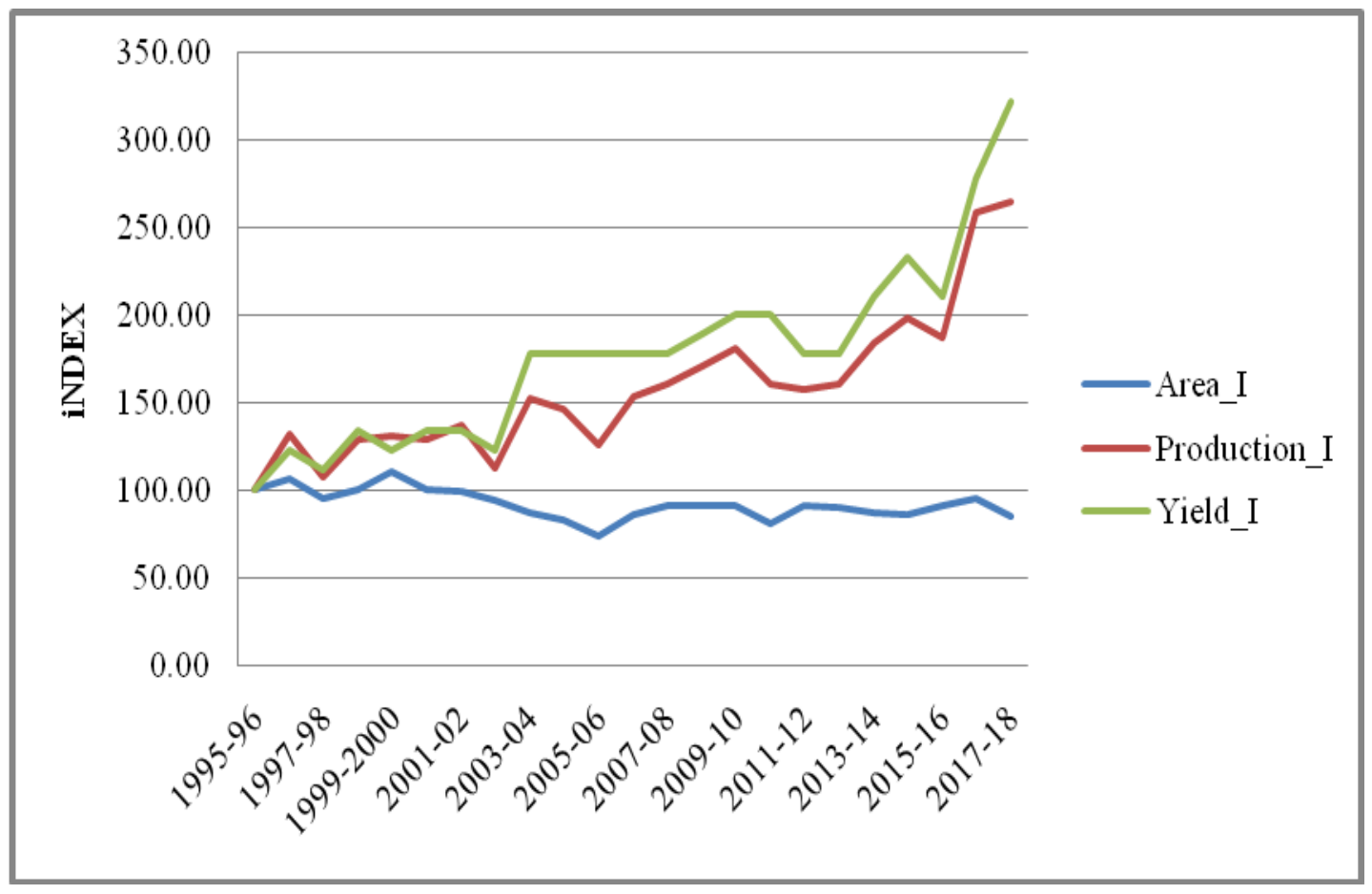


Figure.2 Time Sequence plot of Area of Chilli in India

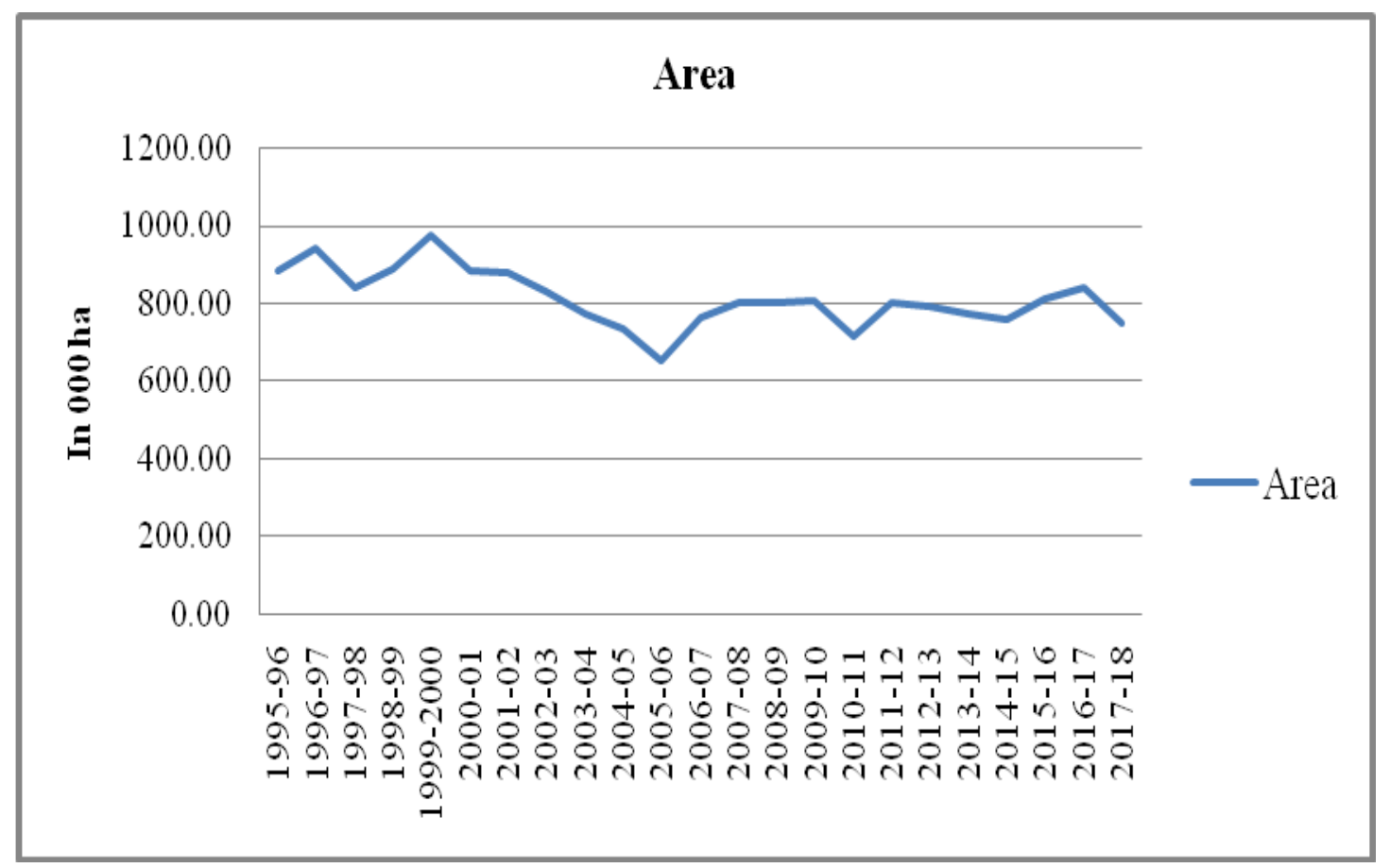

Figure.3 Time Sequence plot of Production of Chilli in India

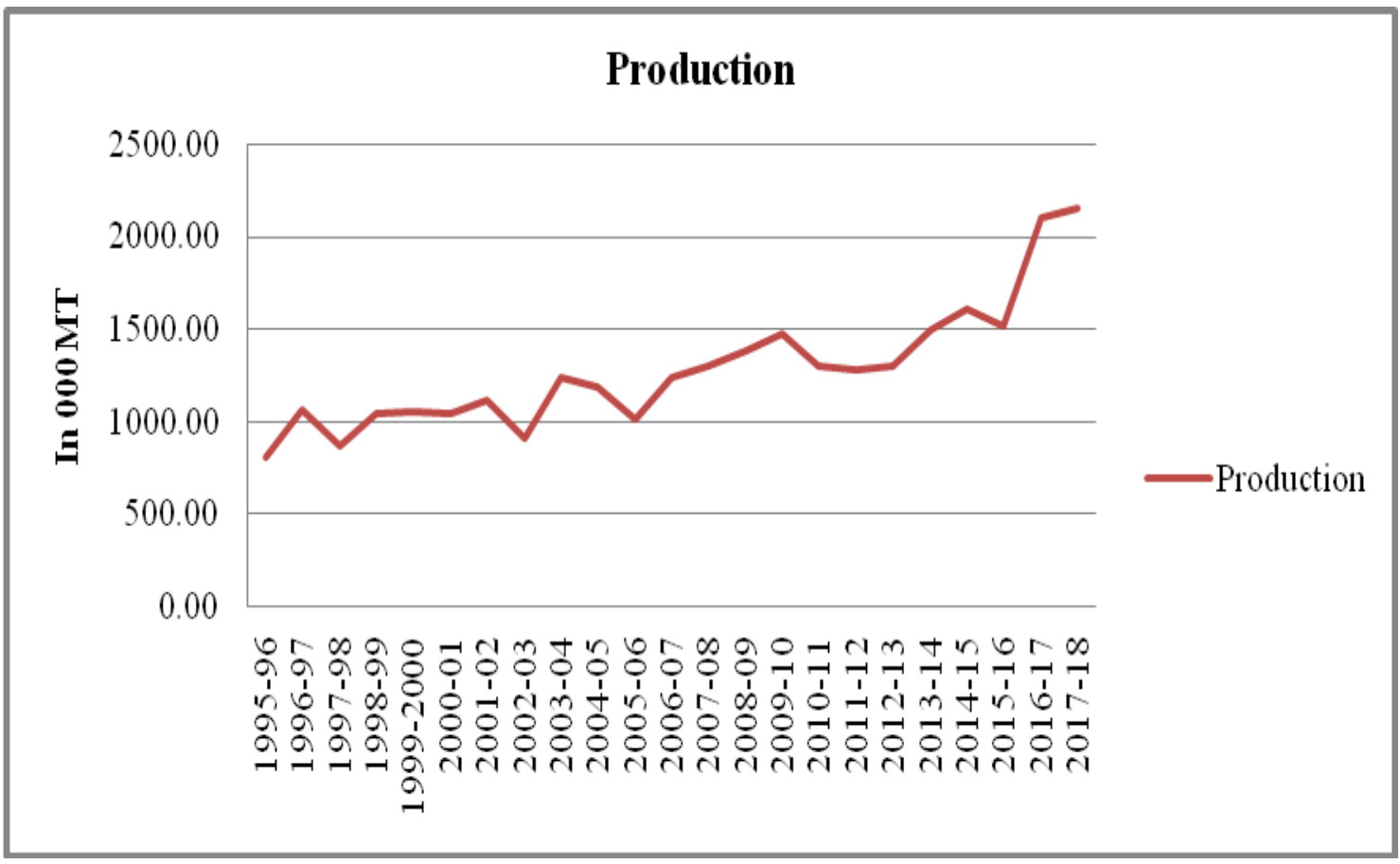


Figure.4 Time Sequence plot of Yield of Chilli in India

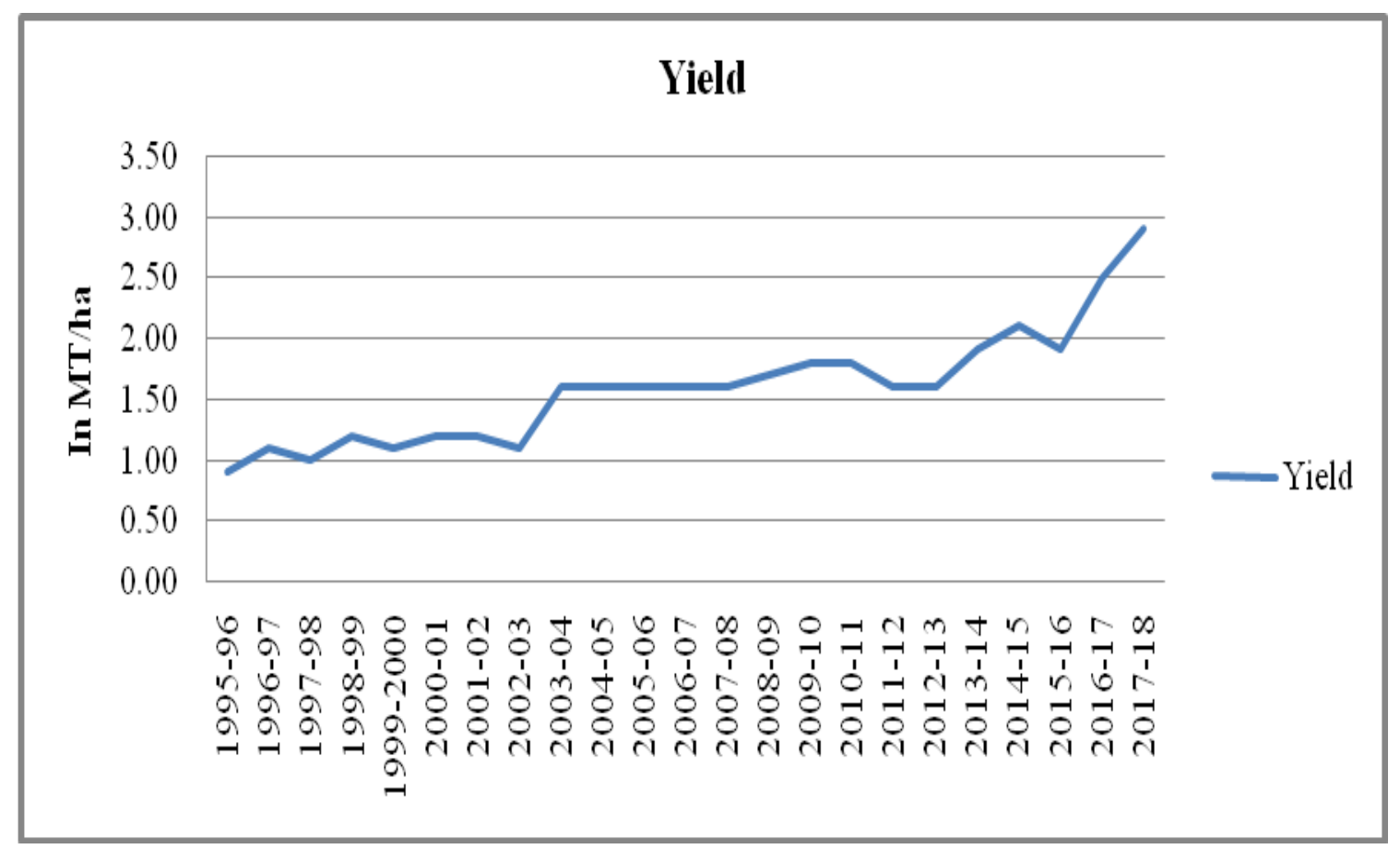

Figure 1 shows the Area, Production and Yield of Chilli in India from period of 199596 to 2017-2018. Graph shows that, area became lower on in the year 1997-98 and quite higher in the year 1999-2000. Area irregularly decreases from the period 1995-96 to 2017-18. Production and yield are parallel to each other. Production and yield are quite higher and constant from 1995-96 to 2002-03, then it continuously increase over the period 2017-18. Compare to production and yield, area decreased from period 1995-96 to 201718 and production and yield increased. With lower cultivation area production and productivity get higher, this was due to modern and improved technology adopted by growers, favorable weather conditions and change in economic environment.

Figure 2 shows the area of chilli in India during the period from 1995-96 to 2017-18 became lower in 1997-98 and quite higher in 1999-2000. Area became highly lower in the year 2005-06. It was continuously decreases till on the period 2017-18. The area of chilli was reduced due to diversified cropping system.

Figure 3 shows the production of chilli in India during the period from 1995-96 to 201718. Production of chilli increased from period 1995-96 to 2017-18. Production of chilli from period 1995-96 to 2005-06 was quietly higher and irregular and from 2005-06 to 2017-18 production were continuously increased and became higher. Over the period production of chilli in India was continuously increased with few exceptional years viz; 1997-98, 2002-03, 2005-06 and 2015-16. This was because of fluctuation in climatic condition, excess \& poor rainfall and lack of government incentives.

Figure 4 shows the yield of chilli in India during the period 1995-96 to 2017-18. Yield of chilli (MT/ha) was continuously increased over the study period. Overall graph of yield shows irregular growth for the overall period 
this is due to higher production per unit area and irregularities due to missing of good package of practice, unfavorable weather.

\section{Instability in area, production and yield of chilli in India}

The instability in area, production and yield was estimated by Cuddy-Della Valle Instability Index. The results are presented in the table 2. During the study period, Coefficient of Variation of chilli area was found to be 0.09 per cent i.e. low variability and Cuddy-Della Valle instability Index (CDI) 0.07 per cent that was also low instability. Coefficient of variation of chilli production and yield was observed to be 0.26 per cent and 0.30 per cent, respectively and that was highly instable. Cuddy-Della Valle instability Index (CDI) for production and yield was observed to be 0.13 per cent and 0.12 per cent respectively. Here observed that area consist lower instability rate, were production as well as yield shows higher instability rate. The instability in productivity was mainly due to unfavorable climatic conditions, pest and disease attack, poor crop protection measures etc. highest growth in production was due to usage of high yielding varieties and adoption of improved package of practice. Similar results were reported by Ashoka et al., (2013).

The following conclusions were emerged from the present study.

The production and yield of chilli was increased but area under chilli cultivation was decreased due to diversified cropping system and only some states of India given importance to chilli cultivation.

The growth rate of area was negative but growth rate of production and yield found positive.
Variability and instability in area found less i.e. 0.09 and 0.07 that means, variation in area of cultivation is poor and lower instable. Variability and instability in production and yield revealed high.

\section{Policy implications}

The area under chilli cultivation is decreasing day by day which has adverse effect on production which ultimately influences export. So government may frame appropriate policy to sustain the area under chilli cultivation.

Need of major preventive measures and solutions on the fluctuation of climatic condition, adverse weather and natural calamities, as well as government should make helping policies for recovery of growers if crops get failed.

\section{References}

Ashoka, N., Kuldeep, C., Ramachandra, V. A., and Yeledhalli, R. A.(2013). A study on growth, instability and direction of chilli trade in India, Journal of Spices and Aromatic Crops, 22 (1): 76-80.

Ganga Devi and Jadav, K. S. (2018). Growth Performance in Area, Production, Productivity and Export of Spices in India, Acta Scientific Agriculture,2(11):87-90.

Joshi, D. and Singh, H. P. (2015). An Empirical Analysis of Growth and Instability In Major Spices In India, International Journal of Agriculture Sciences, 7 (2): 440-444.

Kusuma, D. K. and Kumara, B. R. (2014).Changing direction ofIndian onion exports, International Journal of Agricultural Sciences, 10 (1): 198-201.

Muthupandi, P., Sekhar, C. and Karunakaran, K. R. (2018). Barriers to trade and their 
impact on production and export of red Chilli in India, Indian Journal of Economics and Development,6 (9) : 116.

Ramachandra, V. A., Pavitra, B. S. and Wader, D. G. (2012). Production and export of chillies from India, Agriculture Update, 7(1\&2): 136-141.

Sathish, K., Supriya, K., Bhave, M. H. and Laha, S. (2017). An analysis of growth rate and trend of chilli in Telangana, International Journal of Research in Applied, Natural and Social Sciences, 5(7): 113-120

Shivaji, C., Nagpure, Mhaske, A. R. and Kokate, S.D. (2019). Trade Performance of Banana in India, International Journal of Research and Review, 6 (5):113-123.
Suman, J., Singh, H., Verma, D. K. and Patil, P. (2018). Inter Year Yield Instability of Major Crops in Rajasthan Agriculture, International Journal of Current Microbiology and Applied Sciences, 7: 549-560

Velayutham, L. K. and Damodaran, K. (2015). Growth Rate of Chilli Production in Guntur District of Andhra Pradesh, International Journal of Research in Humanities and Social Studies, 2(11):1-5.

Vijay, P., Leelesh, K. S. and Homendra, S. (2017). Growth rate of chilli production in Raigarh district of Chattisgarh, Bulletine of Environment, Pharmacology and Life Sciences, 6 (1): 587-589.

\section{How to cite this article:}

Gade, P. A., S. S. More, R. D. Shelke and Nalegaonkar, A. R. 2020. Growth and Instability in Area, Production and Yield of Chilli in India. Int.J.Curr.Microbiol.App.Sci. 9(11): 2647-2654. doi: https://doi.org/10.20546/ijcmas.2020.911.321 